\title{
Risk factors associated with milk fever occurrence in grazing dairy cattle
}

\author{
A. Saborío-Montero, ${ }^{* 1}$ B. Vargas-Leitón, † J. J. Romero-Zúñiga,† and J. M. Sánchez* \\ *Animal Nutrition Research Center and Animal Science Department, University of Costa Rica, San José 11501, Costa Rica \\ †Population Medicine Research Program, Veterinary Medicine School, National University of Costa Rica, Heredia 40104, Costa Rica
}

\section{ABSTRACT}

The aim of this study was to determine risk factors associated with milk fever (MF) occurrence in Costa Rican grazing dairy cattle. A total of 69,870 cows from 126 dairy herds were included in the study. Data were collected in the Veterinary Automated Management and Production Control Program software by the Population Medicine Research Program of the Veterinary Medicine School, National University of Costa Rica, from 1985 to 2014. To determine the risk factors for MF, 2 logistic regression mixed models were evaluated. The first model used breed, month of calving, ecological life zone, herd nested within ecological life zone, and parity as fixed effects. The second model excluded firstlactation animals and cows without production information, had the same fixed effects of the first model, and added previous MF case, previous lactation length, previous dry period length, previous corrected 305-d milk yield, and calving interval length as fixed effects. Both models used animal and year as random effects. Of the 235,971 recorded lactations, 4,312 (1.83\%) reported MF event. The significantly associated risk factors for MF occurrence, ranked by their highest odds ratio $(\mathrm{OR})$, were parity $(\mathrm{OR}=52.59)$, previous dry period length $(\mathrm{OR}=4.21)$, ecological life zone $(\mathrm{OR}$ $=3.20)$, breed $(\mathrm{OR}=3.04)$, previous corrected 305$\mathrm{d}$ milk yield $(\mathrm{OR}=2.39)$, previous $\mathrm{MF}$ case $(\mathrm{OR}=$ $2.35)$, and month of calving $(\mathrm{OR}=1.36)$. The findings of this study are the first data reported using an epidemiological approach to study risk factors for MF in Costa Rican dairy cattle. Some of these results might be used to improve preventive management practices at the farms to reduce the incidence of this metabolic disease in grazing dairy herds.

Key words: milk fever, risk factor, dairy cattle, grazing cow

\footnotetext{
Received April 23, 2017.

Accepted August 8, 2017.

${ }^{1}$ Corresponding author: alejandro.saboriomontero@ucr.ac.cr
}

\section{INTRODUCTION}

The transition period in dairy cattle involves important physiological changes, which increase the risk of metabolic imbalances such as clinical hypocalcemia, also known as milk fever (MF; Goff et al., 1987; Goff and Horst, 1997). Milk fever is one of the metabolic diseases that have major negative implications on the profitability of dairy production systems in the United States; the cost per case was estimated at $\$ 334$ (Guard, 1996). In the United Kingdom, the cost of a MF case was valued at $£ 220$ ( $\$ 343$ at a conversion rate of $£ 1.56$ / US\$1.00; Kossaibati and Esslemont, 1996).

The incidence of MF has been reported to be 5 to $7 \%$ of the cows housed in confinement (Goff, 2008), which is similar to that reported by Roche (2003), who reported the incidence of $\mathrm{MF}$ in grazing systems was $5 \%$. A meta-analysis of 135 controlled studies indicated incidences of this disease range from 0 to $83 \%$ (Lean et al., 2006), a range that reveals great potential to influence the incidence of this disease if one understands the factors that are associated with development of MF. Among the risk factors that have been associated with MF are age (the risk increases with increasing age), prepartum diet (high DCAD increases the risk), breed (increased risk for Jersey and Guernsey breeds), milk production (susceptibility increases with herd production), presence of other diseases (increase the likelihood of the imbalance), and background of previous cases (increased risk in animals that have suffered the condition previously; Erb and Gröhn, 1988; Oetzel, 1991; Enevoldsen, 1993).

In Costa Rica, herd-level data collection has been included in the VAMPP (Veterinary Automated Management and Production Control Program) software (Noordhuizen and Buurman, 1984), which has been available to dairy production systems since the mid1980s. Owners, managers, technicians, professionals, and researchers are among the contributors who collected and entered data for the analysis. The VAMPP database contains currently more than 4,000 registered cases of MF.

Costa Rican grazing dairy farms have a combination of singular characteristics (herd size, breed crosses, 
pastures, ecological life zones, robust data frame) that make it interesting to analyze, because some of those features could change the risk factors associated with MF occurrence; therefore, similarities or differences may exist on factors affecting the incidence of this disease compared with other dairy grazing systems of countries, such as New Zealand or Australia, and with countries with confinement farms, such as the United States or Canada.

The epidemiological determination of the main risk factors associated with MF and their relative contribution to the development of this disease in Costa Rica have not been previously reported. The information generated by this type of analysis can lead farms to implement management practices that will reduce the incidence of this disease.

\section{MATERIALS AND METHODS}

\section{Study Design}

A longitudinal observational study design was used to analyze the productive and reproductive data collected in the VAMPP national database between 1985 and 2014. The study population consisted of 69,870 cows from 126 herds, with a total of 235,971 registered calving.

Only those herds that reported at least 5 cases of MF between 1985 and 2014 were included in the study. This procedure was performed to filter and reduce the potential effect of underreporting.

An MF case was any cow entered into the VAMPP national database by the herd managers. It is assumed that a reasonably accurate diagnosis of MF was made by herd managers based on symptomology, such as recumbency, time of development of recumbency relative to calving, and response of the cow to treatment with intravenous calcium.

\section{Statistical Analysis}

The statistical analysis of factors associated with the occurrence of MF was performed using logistic regression (Kleinbaum and Klein, 2010) by generalized linear mixed models. DeGaris and Lean (2008) argued that the models with random effects are better than fixed effects models, as the latter are vulnerable to overdispersion associated with the cluster effect.

In the analyzed data, a single cow could have several cases of MF during its life; thus, in multiparous cows there may be a correlation in the response associated with the animal. Because of the long period of study, year was included as a random effect in the statistical models. Generalized linear mixed models are a highly flexible modeling strategy that allows not only the inclusion of random effects, but also the specifying of different residual correlation structures (SAS Institute Inc., 2010).

In our study, 2 statistical models were proposed, one referred to as the base model and the other called the full model [eq. 1]. In the base model, risk factors not related to the previous lactation were considered, allowing the inclusion of first-calving cows in the analysis. In the full model, factors related to previous lactation $\left[\beta_{6}-\beta_{10}\right.$, eq. 1] were added, so the first-calving females were excluded from this model.

The full model is described as

$$
\begin{gathered}
\operatorname{Logit} \mathrm{P}\left(\mathrm{F}_{\text {ijklmnopqrst }}=1 \mid \mathrm{X}\right)=\left(\beta_{0}+\mathrm{v}_{\mathrm{oi}}\right)+\beta_{1} \mathrm{R}_{\mathrm{j}}+\beta_{2} \mathrm{M}_{\mathrm{k}} \\
+\beta_{3} \mathrm{Z}_{1}+\beta_{4} \mathrm{H}(\mathrm{Z})_{\mathrm{m}}+\beta_{5} \mathrm{~N}_{\mathrm{n}}+\beta_{6} \mathrm{C}_{\mathrm{o}}+\beta_{7} \mathrm{~L}_{\mathrm{p}+} \beta_{8} \mathrm{~S}_{\mathrm{q}} \\
+\beta_{9} \mathrm{P}_{\mathrm{r}}+\beta_{10} \mathrm{I}_{\mathrm{s}}+\mathrm{y}_{\mathrm{ot}}+\varepsilon_{\mathrm{ijklmnopqrst}},
\end{gathered}
$$

where Logit $\mathrm{P}\left(\mathrm{F}_{\mathrm{ijk} k \mathrm{mnopqrst}}=1 \mid \mathrm{X}\right)=$ probability that the ith cow to suffer milk fever belonging to the jth breed, calved at the kth month in the lth ecological life zone, belongs to the mth herd nested within ecological life zone, has nth parity number, oth previous case background of MF, pth previous lactation length, qth previous dry period length, rth previous 305-d corrected milk yield, sth length of calving interval, and calved in the tth year; $\left(\beta_{0}+\mathrm{v}_{\mathrm{oi}}\right)=$ intercept animal-specific for the ith cow; $\beta_{1} R_{j}=$ fixed effect for the $\mathrm{jth}$ breed (Jersey, Holstein $\times$ Jersey crosses, Holstein, Holstein $\times$ Brown Swiss, Brown Swiss, Bos taurus $\times$ Bos indicus, Guernsey, others); $\beta_{2} \mathrm{M}_{\mathrm{k}}=$ fixed effect for the kth month of calving (January to December); $\beta_{3} Z_{1}=$ fixed effect for the lth ecological life zone, as described by Holdridge (1987), specifically montane wet forest, lower montane rain forest, premontane wet forest, lower montane moist forest, premontane moist forest, lower montane wet forest, and tropical wet forest; $\beta_{4} \mathrm{H}(\mathrm{Z})_{\mathrm{m}}=$ fixed effect for the mth herd nested within ecological life zone; $\beta_{5} \mathrm{~N}_{\mathrm{n}}=$ fixed effect for the nth parity $(1,2, \ldots$, $\geq 6) ; \beta_{6} \mathrm{C}_{\mathrm{o}}=$ fixed effect for the oth previous case background of $\mathrm{MF}$ (0/1: absence/presence of previous $\mathrm{MF}$ case); $\beta_{7} \mathrm{~L}_{\mathrm{p}}=$ fixed effect for the pth previous lactation length (12 classes, rounded to the next month, from 4 to 15 and higher); $\beta_{8} \mathrm{~S}_{\mathrm{q}}=$ fixed effect for the qth previous dry period length ( 6 classes, rounded to the next month, from 1 to 6 and higher); $\beta_{9} \mathrm{P}_{\mathrm{r}}=$ fixed effect for the rth previous 305 -d corrected milk yield [7 classes relative to the breed mean $(\mathbf{B M})$, with $1 / 7: \geq 1,500$ $\mathrm{kg}$ below/above BM, 2/6: 1,000 to $1,499 \mathrm{~kg}$ below/ above BM, 3/5: 500 to $999 \mathrm{~kg}$ below/above BM, and 4: $<500 \mathrm{~kg}$ below/above $\mathrm{BM}) ; \beta_{10} \mathrm{I}_{\mathrm{s}}=$ fixed effect for the sth length of calving interval (6 clases, rounded to the 
Table 1. Number of cows, calving, and proportion (\%) of milk fever (MF) cases according to breed, ecological life zone, and parity

\begin{tabular}{lrrr}
\hline Item & $\begin{array}{r}\text { Cows } \\
(\text { no. })\end{array}$ & $\begin{array}{c}\text { Calving } \\
(\text { no. })\end{array}$ & $\begin{array}{c}\text { MF } \\
\text { cases }(\%)\end{array}$ \\
\hline Breed & & & \\
Jersey & 22,289 & 79,196 & 2.72 \\
Holstein $\times$ Jersey & 7,709 & 26,506 & 1.63 \\
Holstein & 27,028 & 92,261 & 1.55 \\
Holstein $\times$ Brown Swiss & 2,620 & 8,098 & 0.83 \\
Brown Swiss & 2,298 & 7,335 & 0.70 \\
Bos taurus $\times$ Bos indicus & 926 & 2,725 & 0.81 \\
Guernsey & 915 & 3,180 & 0.94 \\
Other & 6,085 & 16,670 & 0.73 \\
Total & 69,870 & 235,971 & 1.83 \\
Ecological life zone ${ }^{1}$ & & & \\
MWF & 1,812 & 5,770 & 2.86 \\
LMRF & 4,488 & 16,132 & 1.80 \\
PWF & 17,904 & 55,169 & 1.17 \\
LMMF & 11,089 & 38,841 & 2.48 \\
PMF & 15,621 & 53,435 & 2.61 \\
LMWF & 10,929 & 38,730 & 1.20 \\
TWF & 8,027 & 27,894 & 0.87 \\
Total & 69,870 & 235,971 & 1.83 \\
Parity & & & \\
6 or more & 15,491 & 33,318 & 5.49 \\
5 & 7,703 & 22,070 & 4.18 \\
4 & 9,258 & 30,407 & 2.63 \\
3 & 10,054 & 39,000 & 1.31 \\
2 & 11,757 & 48,969 & 0.37 \\
1 & 15,607 & 62,207 & 0.11 \\
Total & 69,870 & 235,971 & 1.83 \\
\hline
\end{tabular}

${ }^{1}$ Montane wet forest (MWF), lower montane rain forest (LMRF), premontane wet forest (PWF), lower montane moist forest (LMMF), premontane moist forest (PMF), lower montane wet forest (LMWF), and tropical wet forest (TWF).

next month, from 11 to 16 and higher); $\mathrm{y}_{\mathrm{ot}}=$ random effect for the th year of calving; and $\varepsilon=$ randomly distributed residual error with mean zero and common variance.

The described model was solved by GLIMMIX procedure of SAS (SAS Institute Inc., 2010). This procedure estimates the $\beta$ parameters through technical METH$\mathrm{OD}=\mathrm{RSPL}$, corresponding to maximizing residual pseudo log-likelihood with an expansion about current solutions of the best linear unbiased predictors of the random effects (SAS Institute Inc. 2010). In this model the DIST-BIN and LINK-LOGIT options were used to indicate that the response variable follows a binomial distribution with a logit link function (Kleinbaum and Klein, 2010). The odds ratio (OR) were calculated by the model and used as association measurement to interpret the relative propensity to suffer MF in each category within a risk factor.

\section{RESULTS AND DISCUSSION}

\section{Descriptive Statistics}

The number of cows, calvings, and proportion (\%) of MF cases according to breed, ecological life zone, and parity is described in Table 1 . Of the 235,971 registered calvings, $4,312(1.83 \%)$ reported MF. This low occurrence could be affected by underreporting of MF cases. However, the clinical signs of MF are described in a highly specific manner, and therefore the incidence of the disease can be determined from records of treatments (Houe et al., 2001). Calcium participates in the process of muscle contraction, so the symptoms associated with MF are clear and characterized by ataxia, flaccid paresis with recumbence, and, in cases complicated by hypomagnesemia, animals may exhibit seizures. Furthermore, animals respond positively to intravenous infusions, usually containing calcium, magnesium, and glucose (Goff and Horst, 1993).

A previous field trial in 4 Jersey grazing herds in Costa Rica reported incidences of MF of 6, 13, 2, 29, 29 , and $25 \%$ of cows from 1st to 6th parity, respectively, with an overall incidence of $14.5 \%$ (Sánchez and Saborío-Montero, 2014a). However, that study aimed to estimate prevalence of clinical and subclinical hypocalcemia by measuring serum calcium concentrations in each cow $(\mathrm{n}=207)$, which greatly differ from the population approach followed in the present study, which mainly focused on clinical hypocalcemia.

On the other hand, the obtained incidence of MF is consistent with values found in countries whose production systems are based on grazing; in New Zealand, MF was estimated to occur in $2 \%$ of cows (McDougall, 2001), and reported incidences range from 2 to $5 \%$ in Australia (Caple, 1987). Some studies have found differences in the frequency of MF among herds ranging from $<1$ to $>25 \%$ (Mullen, 1975).

Descriptive statistics of covariables analyzed in the full model are shown in Table 2. The full model excluded primiparous cows; therefore, there were fewer data $(\mathrm{n}=123,026)$ than in the base model $(\mathrm{n}=235,971)$.

Table 2. Descriptive statistics of covariables analyzed in the full model

\begin{tabular}{|c|c|c|c|c|c|c|}
\hline Item & $\mathrm{n}$ & Mean & Median & SD & Minimum & Maximum \\
\hline Previous dry period length (d) & 123,026 & 80.3 & 65.0 & 47.2 & 10 & 500 \\
\hline Previous 305-d milk yield (kg) & 123,026 & $6,020.3$ & $5,895.0$ & $1,824.3$ & 500 & 12,500 \\
\hline
\end{tabular}


Table 3. Risk factors for milk fever occurrence in Costa Rican dairy cattle from 2 logistic regression mixed model analysis for base and full models

\begin{tabular}{lrrr}
\hline Risk factor & df & $F$ value & $P$-value \\
\hline Base model $^{1}$ & & & \\
Breed & 7 & 7.09 & $<0.0001$ \\
Month of calving & 11 & 2.04 & 0.0208 \\
Ecological life zone & 6 & 18.33 & $<0.0001$ \\
Herd (nested within zone) & 120 & 19.12 & $<0.0001$ \\
Parity $_{\text {Full model }}^{2}$ & 5 & 487.52 & $<0.0001$ \\
Breed & 6 & 4.22 & $<0.0003$ \\
Month of calving & 11 & 1.95 & 0.0287 \\
Ecological life zone & 6 & 11.68 & $<0.0001$ \\
Herd (nested within zone) & 117 & 14.49 & $<0.0001$ \\
Parity & 4 & 255.62 & $<0.0001$ \\
Previous milk fever case background $_{\text {Previous lactation length }}$ & 1 & 276.00 & $<0.0001$ \\
Previous dry period length $_{\text {Previous 305-d corrected milk yield }}$ & 11 & 1.70 & 0.0657 \\
Calving interval length $^{2}$ & 5 & 5.48 & $<0.0001$ \\
\end{tabular}

${ }^{1}$ Fit statistics: -2 Res $\log$ pseudo-likelihood $=1,982,144$; covariance estimate for year effect $=0.05259$; standard error of covariance estimate $=0.01799$; residual $=1.0917$; standard error of the residual $=0.00318$.

${ }^{2}$ Fit statistics: -2 Res log pseudo-likelihood $=928,938$; covariance estimate for year effect $=0.1169$; Standard error of covariance estimate $=0.04123$; residual $=1.0264 ;$ standard error of the residual $=0.004142$.

\section{Results of Statistical Models}

The base model determined 5 risk factors $(P<0.05)$ associated with MF. For the full model, 8 risk factors were statistically associated with the disease (Table 3 ).

The OR associated with each risk factor for MF occurrence in both statistical models are described in Table 4. The OR associated with each risk factor for MF occurrence, exclusively in the full model, is described in Table 5.

\section{Parity}

Parity was by far the factor posing the greatest risk for development of MF in both models (Table 4). The risk of developing MF increased with parity in both models of analysis. The base model maximized the magnitude of the OR for MF being caused by parity because it used first-calving cows as the reference category, and those cows rarely develop MF. In the full model, the reference category was second-calving cows, which are more prone to MF than first-calving cows. This reduced the magnitude of the OR for MF risk with higher calving number.

These findings agree with other studies (Schultz, 1971; Gröhn et al., 1989; Horst et al., 1997; Uribe, 1998; Reinhardt et al., 2011), in which the probabilities of suffering MF increased with parity. Roche and Berry (2006) determined that cows of 4th and 5th calving had 2.30 and 7.43 times the chance of develop MF using third-calving cows as reference. The possible causes that explain this effect may be less capacity to move calcium from bone (van Mosel et al., 1993), reduction in transport of intestinal calcium, and decrease in production of 1,25- $(\mathrm{OH})_{2} \mathrm{D}_{3}$ in older cows (Horst et al., 1990, 1997).

\section{Breed}

The Jersey breed showed the highest OR for MF occurrence, and the Brown Swiss was set as the reference breed because of its reduced likelihood to suffer the disease (Table 4). The greater susceptibility to MF in the Jersey breed has been previously reported (Curtis et al., 1970; Harris, 1981; Erb and Gröhn, 1988). Roche and Berry (2006) found that the Jersey breed had 4.96 times the chance of having MF compared with Holstein and that Holstein $\times$ Jersey crossing had 2.44 times the chance of developing the disease in relation to Holstein breed. Likewise, a meta-analysis by Lean et al. (2006) showed that Jersey cows had 2.37 times the chance of having MF compared with the Holstein breed. In Costa Rica, Sánchez and Saborío-Montero (2014b) reported higher prevalence of clinical hypocalcemia in Jersey cows compared with Holstein and Guernsey under the same feeding, management, and environmental conditions. The reason the Jersey breed is more prone to MF has not been elucidated yet. However, at least one study (Goff et al., 1995) states that this increased susceptibility to disease could be the result of fewer receptors for $1,25(\mathrm{OH})_{2} \mathrm{D}_{3}$ in the intestine. Increased calcium concentrations in Jersey cow colostrum has also been considered a possible explanation for increased $\mathrm{MF}$ in Jerseys (NRC, 2001). 
Table 4. Odds ratio (OR) for milk fever in Costa Rican dairy cattle according to risk factors categories, estimated in the full and base model by logistic regression mixed models ${ }^{1}$

\begin{tabular}{|c|c|c|c|c|c|c|}
\hline Risk factors category & \multicolumn{3}{|c|}{ Full model } & \multicolumn{3}{|c|}{ Base model } \\
\hline \multicolumn{7}{|l|}{ Parity } \\
\hline$\geq 6$ & 12.84 & 10.65 & 15.47 & 52.59 & 40.92 & 67.59 \\
\hline 5 & 11.10 & 9.17 & 13.44 & 38.76 & 30.02 & 50.04 \\
\hline 2 & 1 & - & - & 3.24 & 2.43 & 4.33 \\
\hline 1 & - & - & - & 1 & - & - \\
\hline \multicolumn{7}{|l|}{ Breed } \\
\hline Jersey & 3.04 & 1.65 & 5.61 & 2.29 & 1.44 & 3.64 \\
\hline Holstein $\times$ Jersey crosses & 2.53 & 1.38 & 4.65 & 1.93 & 1.21 & 3.07 \\
\hline Holstein $\times$ Brown Swiss crosses & 2.19 & 1.20 & 4.02 & 1.75 & 1.19 & 2.58 \\
\hline Holstein & 1.61 & 1.09 & 2.39 & 1.59 & 1.01 & 2.51 \\
\hline April & 1.23 & 1.03 & 1.46 & 1.20 & 1.02 & 1.40 \\
\hline September & 1.21 & 1.01 & 1.44 & 1.22 & 1.04 & 1.43 \\
\hline December & 1 & - & - & 1 & - & - \\
\hline \multicolumn{7}{|l|}{ Ecological life zone ${ }^{2}$} \\
\hline MWF & 3.20 & 2.32 & 4.43 & 3.09 & 2.36 & 4.04 \\
\hline LMRF & 2.29 & 1.73 & 3.02 & 2.56 & 2.06 & 3.19 \\
\hline PWF & 2.18 & 1.69 & 2.83 & 2.02 & 1.65 & 2.47 \\
\hline LMMF & 1.77 & 1.39 & 2.26 & 1.99 & 1.61 & 2.46 \\
\hline PMF & 1.77 & 1.39 & 2.27 & 2.09 & 1.71 & 2.56 \\
\hline LMWF & 1.50 & 1.18 & 1.90 & 1.56 & 1.27 & 1.91 \\
\hline TWF & 1 & - & - & 1 & - & - \\
\hline
\end{tabular}

${ }^{1}$ The risk factors categories are ordered decreasingly according to the intensity of association with the occurrence of milk fever in the full model; nonsignificant categories were excluded from Table 3. LB $=$ lower bound; UB = upper bound.

${ }^{2}$ Montane wet forest (MWF), lower montane rain forest (LMRF), premontane wet forest (PWF), lower montane moist forest (LMMF), premontane moist forest (PMF), lower montane wet forest (LMWF), and tropical wet forest (TWF).

\section{Ecological Life Zone}

Because of the effects of weather conditions on dairy grazing systems, 7 ecological life zones were used to estimate the effect of zone on MF occurrence. Ecological life zone was statistically associated $(P<0.0001)$ with $\mathrm{MF}$ and was a risk factor for MF occurrence in the current study (Table 3). Montane wet forest was the ecological life zone with the highest OR for MF occurrence in both the base $(\mathrm{OR}=3.09)$ and full $(\mathrm{OR}=3.20)$ models, and tropical wet forest was the ecological life zone with the lowest risk of MF (reference category). Montane was the highest altitudinal belt and the lowest temperature classification of all ecological life zones analyzed, other lower altitudinal belts were also classified as wet forest, which suggests that cows grazing on farms located on higher altitudinal belt could be more prone to MF. The effect associated with the weather characteristics pertaining to any area may also be associated with pastures used in the farms located in a specific area and in its composition. At least one study conducted in Costa Rica found a DCAD in Kikuyu ( $\mathrm{Ki}$ kuyuocloa clandestina) as high as $+665 \mathrm{mEq} / \mathrm{kg}$ of $\mathrm{DM}$ (Sánchez and Saborío-Montero, 2014a); this study was conducted on 4 farms of the Montane altitudinal belt, whereas other grasses (Cynodon nlemfuensis) sampled on lower altitudinal belts had lower DCAD (366 mEq/ $\mathrm{kg}$ of DM) in Costa Rican pastures (Sánchez, 1995).

\section{Herd Within Zone}

The herd nested within ecological life zone was a risk factor for MF (Table 3). The occurrence of MF ranged from 1 to $28 \%$; each dairy farm had its own management in terms of diet supplementation before calving, pasture consumption, and prophylactic treatments. Consequently, many factors within a herd can increase or reduce the likelihood for cows to suffer MF. Average herd size in the current study was 114 cows (95\% CI = 97.9-130.4). Some researchers (Lean et al., 2006) have 
also found huge differences on incidence of MF (0-83\%) in controlled studies.

\section{Month of Calving}

Month of calving was a risk factor for occurrence of MF $(P<0.05)$ in both models of analysis (Table 4). The higher likelihood of MF in both models was obtained for July and May; December was the least risky month to develop MF. The susceptibility to MF on grazing cows could be influenced by pasture nutritional composition, which changes trough the months of the year (Villalobos and Arce, 2014; Villalobos and Sánchez, 2010); specifically, the mineral content of the diet could change the likelihood to suffer MF (Horst et al., 1997). Regarding mineral absorption in the most commonly used grasses in dairy farms from Costa Rica, Salas and Cabalceta (2009) reported that potassium was the most absorbed mineral in Kikuyu (Kikuyuocloa clandestina), Toledo (Brachiaria brizantha L. 'Toledo'), and Star Grass (Cynodon nlemfluensis) pastures. They also mentioned that the absorption of potassium increased with grass DM per unit of area in those grasses. Potassium is one of the cations used to estimate the DCAD and has been associated with MF occurrence previously (Horst et al., 1997). However, the reason

Table 5. Odds ratio (OR) for milk fever in Costa Rican dairy cattle according to risk factors categories, estimated in the full model by logistic regression mixed models

\begin{tabular}{|c|c|c|c|}
\hline \multirow[b]{3}{*}{ Risk factors category } & \multicolumn{3}{|c|}{ Full model $^{1}$} \\
\hline & \multirow[b]{2}{*}{ OR } & \multicolumn{2}{|c|}{ CI $95 \%$} \\
\hline & & LB & $\mathrm{UB}$ \\
\hline \multicolumn{4}{|l|}{ Previous 305-d corrected milk yield ${ }^{2}$} \\
\hline $7:>1,500 \mathrm{~kg}$ from $\mathrm{BM}$ & 2.39 & 2.02 & 2.82 \\
\hline 6: 1,000 to $1,499 \mathrm{~kg}$ from $\mathrm{BM}$ & 2.12 & 1.78 & 2.52 \\
\hline 5: 500 to $999 \mathrm{~kg}$ from $\mathrm{BM}$ & 2.00 & 1.69 & 2.38 \\
\hline 4: -499 to $499 \mathrm{~kg}$ from $\mathrm{BM}$ & 1.83 & 1.55 & 2.16 \\
\hline $3:-500$ to $-999 \mathrm{~kg}$ from $\mathrm{BM}$ & 1.66 & 1.40 & 1.96 \\
\hline $2:-1,000$ to $-1,499 \mathrm{~kg}$ from $\mathrm{BM}$ & 1.37 & 1.15 & 1.64 \\
\hline 1: $<-1,500 \mathrm{~kg}$ from $\mathrm{BM}$ & 1 & - & - \\
\hline \multicolumn{4}{|l|}{ Previous dry period length ${ }^{3}$} \\
\hline$>6 \mathrm{mo}$ & 3.38 & 1.84 & 6.23 \\
\hline $5 \mathrm{mo}$ & 4.21 & 2.31 & 7.66 \\
\hline $4 \mathrm{mo}$ & 3.72 & 2.07 & 6.66 \\
\hline $3 \mathrm{mo}$ & 3.77 & 2.13 & 6.66 \\
\hline $2 \mathrm{mo}$ & 3.44 & 1.95 & 6.07 \\
\hline$\leq 1 \mathrm{mo}$ & 1 & - & - \\
\hline \multicolumn{4}{|l|}{ Previous milk fever case } \\
\hline With previous case & 2.35 & 2.13 & 2.60 \\
\hline Without previous case & 1 & - & - \\
\hline
\end{tabular}

${ }^{1} \mathrm{LB}=$ lower bound; UB = upper bound.

${ }^{2}$ Previous $305-\mathrm{d}$ corrected milk yield was categorized into 7 classes relative to breed mean (BM).

${ }^{3}$ Previous dry period length was categorized into monthly classes, rounded to the next month. why cows that calved in July and May were more prone to MF could not be elucidated was because neither nutritional composition nor biomass availability estimation of grasses was recorded on the farms. This effect may be associated with the onset of the rainy season in those months. The increased precipitation could change the DCAD in grasses being grazed as well as grass DM availability which might be inductive to MF.

\section{Previous Case of MF}

The analysis of history of MF in the full model indicated animals that had suffered MF at an earlier calving were $2.35(95 \% \mathrm{CI}=2.13-2.60)$ times more likely to experience the event again compared with animals whose background was negative for the disease (Table $5)$. This effect of increased risk of MF in animals with a background of previous cases is consistent with that reported in a study on the epidemiology of metabolic disorders in periparturient dairy cows, which stated that an animal that has undergone previous illness due to MF has 2 to 5 times the chance of developing MF again (Erb and Gröhn, 1988). Similarly, the model estimate of increased risk for MF in cows with a history of previous MF was very close to that reported by Roche and Berry (2006), who found that the likelihood of MF was 2.2 times higher in cows that developed MF in the previous lactation relative to those who did not develop the disease in a previous year.

\section{Previous 305-d Corrected Milk Yield}

The corrected 305-d milk yield in the previous lactation was a significant risk factor $(P<0.0001)$ to develop MF in the full model. An increase of $1,500 \mathrm{~kg}$ of milk over the breed average yield generated an OR of 2.39 (95\% CI $=2.02-2.82)$ for MF likelihood using cows yielding $1,500 \mathrm{~kg}$ less than the breed average yield as reference (Table 5). Previous studies have linked MF to more productive cows (Gröhn et al., 1989); and also have reported an increased incidence of the disease as a result of increased levels of production (Payne, 1977). One possible explanation for this effect is that cows with higher productive potential could yield more colostrum, and therefore the loss of calcium in this way could be higher than in animals with lower milk production potential (Liesegang et al., 1998, 2000).

\section{Previous Dry Period Length}

Previous dry period length $\leq 1$ mo was the reference category and calving with $2,3,4,5$, and 6 mo of previous dry period length were $3.44,3.77,3.72,4.21$, and 3.38 times more susceptible to suffer MF, respectively; 
only the reference category statistically differed $(P<$ $0.0001)$ from the others. In a review of milk fever control principles, Thilsing-Hansen et al. (2002) reported that shortening of the dry period has been used as possible but less specific control measures for the prevention of MF than other preventive managements. Davicco et al. (1992) found that cows with previous dry period length of $4 \mathrm{~d}$ have less profound postparturient drop in blood calcium compared with an 8-wk previous dry period length. Morrow et al. (1979) stated that cows with long nonlactating periods have more quiescent calcium homeostasis; however, Sørensen and Enevoldsen (1991) reported significant reduction in milk yield when shortening the previous dry period length from 7 to $4 \mathrm{wk}$.

\section{Previous Lactation Length and Calving Interval}

In the full model neither previous lactation length nor calving interval length showed statistical association with MF propensity (Table 3).

\section{CONCLUSIONS}

Parity was by far the most important risk factor associated with the occurrence of MF. Other factors, such as previous dry period length, ecological life zone, herd nested within zone, breed, previous corrected 305-d milk yield, history of a previous case of MF, and month of calving, were also risk factors for the occurrence of MF in grazing cows. Some of these factors have been reported previously in grazing or confinement dairy systems; however, others, such as ecological life zone, have never been mentioned. Knowledge of these risk factors and its relative importance is considered relevant to improve the preventive management of this disease in dairy herds.

\section{ACKNOWLEDGMENTS}

We acknowledge financial support from the University of Costa Rica (grant number 739-B5091), and are also grateful to J. P. Goff (Anderson Chair in Veterinary Medicine, College of Veterinary Medicine, Iowa State University, Ames) for the revision of the draft. We thank the Regional Informatics Center for Sustainable Animal Production (CRIPAS) of the Veterinary Medicine School, National University of Costa Rica, for allowing us to use the data for this study.

\section{REFERENCES}

Caple, I. W. 1987. Unravelling mineral and metabolic problems in dairy herds. Pages 19-21 in Australian Advances in Veterinary Science. Proc. 64th Annu. Conf. Aus. Vet. Assoc.
Curtis, R. A., J. F. Cote, and A. Mills. 1970. An epizootiological study of parturient paresis (milk fever). Pages 81-85 in Parturient Hypocalcemia. J. B. Anderson, ed. Academic Press Inc., New York, NY.

Davicco, M. J., B. Rémond, S. Jabet, and J. P. Barlet. 1992. Plasma osteocalcin concentrations in cows around parturition. The influence of a regular versus a very short dry period. Reprod. Nutr. Dev. 32:313-319.

DeGaris, P. J., and I. J. Lean. 2008. Milk fever in dairy cows-a review of pathophysiology and control principles. Vet. J. 176:58-69.

Enevoldsen, C. 1993. Nutritional risk factors for milk fever in dairy cattle: Meta-analysis revisited. Acta Vet. Scand. Suppl. 89:131134.

Erb, H. N., and Y. T. Gröhn. 1988. Epidemiology of metabolic disorders in the periparturient dairy cow. J. Dairy Sci. 71:2557-2571.

Goff, J. P. 2008. The monitoring prevention and treatment of milk fever and subclinical hypocalcemia in dairy cows. Vet. J. 176:50-57.

Goff, J. P., and R. L. Horst. 1993. Oral administration of calcium salts for treatment of hypocalcemia in cattle. J. Dairy Sci. 76:101-108.

Goff, J. P., and R. L. Horst. 1997. Physiological changes at parturition and their relationship to metabolic disorders. J. Dairy Sci. 80:1260-1268.

Goff, J. P., R. L. Horst, and T. A. Reinhardt. 1987. The pathophysiology and prevention of milk fever. Vet. Med. 82:943-950.

Goff, J. P., T. A. Reinhardt, and R. L. Horst. 1995. Milk fever and dietary cation-anion balance effects on concentration of vitamin D receptor in tissue of periparturient dairy cows. J. Dairy Sci. 78:2388-2394.

Gröhn, Y. T., H. N. Erb, C. E. Mc Culloch, and H. S. Saloniemi. 1989. Epidemiology of metabolic disorders in dairy cattle: Association among host characteristics, disease and production. J. Dairy Sci. $72: 1876-1885$.

Guard, C. L. 1996. Fresh cow problems are costly: Culling hurts the most. Hoards Dairyman 141:8.

Harris, D. J. 1981. Factors predisposing to parturient paresis. Aust. Vet. J. 57:357-361.

Holdridge, L. R. 1987. Ecología basada en zonas de vida. Traducido por Humberto Jiménez Saa. Instituto Interamericano de Ciencias Agrícolas (IICA), San José, Costa Rica.

Horst, R. L., J. P. Goff, and T. A. Reinhardt. 1990. Advancing age results in reduction of intestinal and bone 1,25-dihydroxyvitamin D receptor. Endocrinology 126:1053-1057.

Horst, R. L., J. P. Goff, T. A. Reinhardt, and D. R. Buxton. 1997. Strategies for preventing milk fever in dairy cattle. J. Dairy Sci. 80:1269-1280.

Houe, H., S. Ostergaard, T. Thilsing-Hansen, R. J. Jorgensen, T. Larsen, J. T. Sorensen, J. F. Agger, and J. Y. Blom. 2001. Milk fever and subclinical hypocalcemia an evaluation of parameters on incidence risk diagnosis, risk factors and biological effects as input for a decision support system for disease control. Acta Vet. Scand. 42:1-29.

Kleinbaum, D. G., and M. Klein. 2010. Logistic Regression: A SelfLearning Text. 3rd ed. Statistics for Biology and Health. Springer Editorial, New York, NY.

Kossaibati, M. A., and R. J. Esslemont. 1996. DAISY - The Dairy Information System Report $\mathrm{N}^{\circ} 4$. In Wastage in Dairy Herds. Department of Agriculture, Earley Gate, The University of Reading.

Lean, I. J., P. J. DeGaris, D. M. Mc Neil, and E. Block. 2006. Hypocalcemia in dairy cows: Meta-analysis and dietary cation anion difference theory revisited. J. Dairy Sci. 89:669-684.

Liesegang, A., R. Eicher, M. L. Sassi, J. Risteli, M. Kraenzlin, J. L. Riond, and M. Wanner. 2000. Biochemical markers of bone formation and resorption around parturition and during lactation in dairy cows with high and low standard milk yields. J. Dairy Sci. 83:1773-1781.

Liesegang, A., M. L. Sassi, J. Risteli, R. Eicher, M. Wanner, and J. L. Riond. 1998. Comparison of bone resorption markers during hypocalcemia in dairy cows. J. Dairy Sci. 81:2614-2622.

McDougall, S. 2001. Effects of periparturient diseases and conditions on the reproductive performance of New Zealand dairy cows. N. Z. Vet. J. 49:60-67. 
Morrow, D. A., D. Hillman, A. W. Dade, and Y. Kitchen. 1979. Clinical investigation of dairy herd with the fat cow syndrome. J. Am. Vet. Med. Assoc. 174:161-167.

Mullen, P. A. 1975. Clinical and biochemical responses to the treatment of milk fever. Vet. Rec. 97:87-92.

NRC. 2001. Nutrient Requirements of Dairy Cattle. 7th rev. ed. Natl. Acad. Press, Washington, DC.

Noordhuizen, J. P., and J. Buurman. 1984. VAMPP: A veterinary automated management and production control programme for dairy farms (the application of MUMPS for data processing). Vet. Q. 6:66-72.

Oetzel, G. R. 1991. Meta-analysis of nutritional risk factors for milk fever in dairy cattle. J. Dairy Sci. 74:3900-3912.

Payne, J. M. 1977. Parturient paresis. Pages 61-83 in Metabolic Diseases in Farm Animals. Heinemann Medical Books, London, UK.

Reinhardt, T. A., J. D. Lippolis, B. J. Mc Cluskey, J. P. Goff, and R. L. Horst. 2011. Prevalence of subclinical hypocalcemia in dairy herds. Short communication. Vet. J. 188:122-124.

Roche, J. R. 2003. The incidence and control of hypocalcemia in pasture-based systems. Acta Vet. Scand. Suppl. 97:141-144.

Roche, J. R., and D. P. Berry. 2006. Periparturient climatic, animal, and management factors influencing the incidence of milk fever in grazing systems. J. Dairy Sci. 89:2775-2783.

Salas, R., and G. Cabalceta. 2009. Manejo del Sistema Suelo-Pasto: partida para la producción de forrajes. Cámara Nacional de Productores de Leche, Costa Rica, Congreso Nacional Lechero 2009. http://www.proleche.com/recursos/documentos/congreso2009/ Manejo-del-sistema-suelo-pasto.pdf.

Sánchez, J. M. 1995. El balance cation-anión en la nutrición del ganado lechero. Nutrición Animal Tropical 2:3-29.

Sánchez, J. M., and A. Saborío-Montero. 2014a. Prevalencia de hipocalcemia en cuatro hatos Jersey en pastoreo en Costa Rica. Agronomía Costarricense 38:33-41.
Sánchez, J. M., and A. Saborío-Montero. 2014b. Hipocalcemia e hipomagnesemia en un hato de vacas Holstein, Jersey y Guernsey en pastoreo. Agronomía Costarricense 38:55-65.

SAS Institute Inc. 2010. The GLIMMIX Procedure in SAS/STAT 9.22 User's Guide. SAS Institute Inc., Cary, NC.

Schultz, L. H. 1971. Milk fever and ketosis. Pages 321-340 in Digestive Physiology and the Nutrition of Ruminants. Vol. 2. 2nd ed. D. C. Church, ed. Oliver and Boyd Books, Corvallis, OR.

Sørensen, J. T., and C. Enevoldsen. 1991. Effect of dry period length on milk production in subsequent lactation. J. Dairy Sci. 74:12771283.

Thilsing-Hansen, T., R. J. Jørgensen, and S. Østergaard. 2002. Milk fever control principles: A review. Acta Vet. Scand. 43:1-19.

Uribe, H. A. 1998. Cuantificación de factores de riesgo para mastitis, quistes ováricos, hipocalcemia y cetosis usando regresión logística en ganado Holstein. Arch. Med. Vet. 30:177-190.

van Mosel, M., A. T. van't Klooster, F. van Mosel, and J. van der Kuilen. 1993. Effects of reducing dietary $\left[\left(\mathrm{Na}^{+}+\mathrm{K}^{+}\right)-\left(\mathrm{Cl}^{-}+\mathrm{SO}_{4}{ }^{=}\right)\right]$ on the rate of calcium mobilization by dairy cows at parturition. Res. Vet. Sci. 54:1-9.

Villalobos, L., and J. Arce. 2014. Evaluación agronómica y nutricional del pasto Estrella Africana (Cynodon nlemfuensis) en la zona de Monteverde, Puntarenas, Costa Rica. II. Valor Nutricional. Agronomía Costarricense 38:133-145.

Villalobos, L., and J. Sánchez. 2010. Evaluación agronómica y nutricional del pasto Rye Grass perenne tetraploide (Lolium perenne) producido en lecherías de las zonas altas de Costa Rica. II. Valor Nutricional. Agronomía Costarricense 34:43-52. 